\title{
Implications of Street Trading Activities on the Residents within Central Business Districts in Nigeria.
}

\author{
Taiwo, David Olugbenga ${ }^{1}$ and Akinyode, Babatunde Femi ${ }^{2}$ \\ ${ }^{I}$ Department of Urban and Regional Planning, The Federal Polytechnic, Ado-Ekiti, Nigeria \\ ${ }^{2}$ Department of Urban and Regional Planning, LadokeAkintola University of Technology, Ogbomoso, Nigeria.
}

\begin{abstract}
Various illegal activities through roads' occupants pose many socio-economic and environmental challenges to residents living in and around city centres. Among these activities is street trading. Until date, street trading activities constitute one of unresolved challenges to motorists, pedestrians andresidents within central business districts (CBD) in Nigeria. This study aimed at examining implications of street trading activitieson the residents within CBD in Nigeria using Ado-Ekiti as the study area. The study utilized quantitative and qualitative methods in data collection. Quantitative method employed administration of 248 questionnaires. Interviews conducted among various stakeholders and personal observations were employed in Qualitative method. Out of 248 questionnaires, a total of 100 questionnaires were retrieved which represented 40.32 percent response rate. The analysis was based upon these 100 questionnaires with the use of descriptive and chi-square analysis. Qualitative aspect of the study employed content analysis. The study discovered environmental degradation, traffic congestion, overcrowding within the CBD and deplorable state of social amenities as the implications of street trading activities within the CBD. The authors are of the opinion that, policy measures that incorporate design of ultra-modern markets, motor parks and public enlightenment to the street traders may be of assistance to solve the problems of street trading activities within CBD in developing countries.
\end{abstract}

\section{Keywords Ado-Ekiti, Central Business District, Environmental, Street trading, Vehicular}

\section{INTRODUCTION}

The continuous rise in urbanisation because of poverty and dearth in gainful employment levels both in the rural areas and in the smaller towns has driven quite a large number of people to the cities in order to search for job and livelihood, has been of great concern globally. The rapid growth of most of the state capitals in Nigeria that brought into existence unplanned neighbourhood and physical growth of the traditional centres has also become a great concern to both planners and the policy makers [1]. Since the early sixties, the situation that resulted from rural-urban migration has created several unresolved problems [2]. The issue of street trading activities has being in existence from time immemorial. In most cities of the developing countries, sustenance of urban poor has been on informal sector activities. Majority of these people were of low educational level and possessed low skills that are required for employment in the formal sector [3]. Street trader is one of the several sub-groups in the informal economy operating in a visible but contested domain within African settings [4].Several studies have revealed that, a large number of street traders involved in street trading because of lack of means for livelihood, survivaland their inability to pay the rents for the available few shops [5]. Street trading does not require special skills or training. However, the income generation is low as the investment on it is low but the people involved in it found it as easiest form for earning a livelihood [3]. Urban migrants, who are drawn from the rural areas, are often confronted with the problems of making two ends meet. As a result of this, they eventually end up to street trading. This is because; the urban centres are already over-whelmed to the extent that as the receiving centre, the existing social services cannot cope with the actual demand by the increasing population [5]. [1] observed that in sub-Saharan Africa, the informal economy has been the main source of urban jobs for the escalating urban poor. According to [4], the informal employment accounts for about 60 per cent of all urban jobs and over 90 per cent of all new jobs created during the 1990s. [5] took an historical look at the practice of street trading and concluded that it is primordial. The practice of street trading has come neither overnight nor because of civilization. The practice was not also an outcome of city development but has been from generation to generation. However, this is the way people misuse or violate urban planning regulation guiding the development [3]. The land use in the core area of Ado Ekiti is basically commercial, residential, public uses and in some cases mixed uses. Surrounding the major roads at the core area are commercial uses located at the front of the buildings in the area. There are some light industries such as 
bakeries which are within residential area and are enclosed with either shops or market shed to display products $[6,7]$.

The continuous wave of street trading arises from the structural inequalities caused by poverty. This in essence, has brought about adverse economic environment, under-employment and poor quality of life. Massive retrenchment and unemployment have reflected in various way and these include dearth of social services, acute shortage of good housing, inadequate food supply and health care services [3].[8] observed that the prevailing situation has compelled the least privileged children and children without parents to engage themselves in street trading activities. Some of the consequences of this include; destruction of the environment, paucity of adequate infrastructure and amenities, marginal land/urban fringe proliferation and urban poverty amongst others [9]This study focused on the effect of street trading activities within central business districts (CBD) in Nigeria using Ado-Ekiti as a study area The study examined various street trading activities within the study areas, the socioeconomic attributes of the street traders and the motives behind street trading. The study then assessed the physical implications of street trading activities on the roads' users and the residents within the CBD. Until recently, studies specifically addressing the effects of street trading activities on the residentswithinCBDin Nigeria with particular reference to Ado Ekiti are lacking. This study therefore addresses this gap and adds to the body of knowledge.

\section{METHODOLOGY}

The data for this study were derived through quantitative and qualitative methods. The two methods were employed so that each methodwill complement the other. Data were obtained in quantitative methods through the administration of a structured questionnaire. The conduct of interview with some stakeholders and personal observation were adopted in the qualitative method of data collection. This is mainly to get information that may be useful to achieve the aim of this study but that may not be possible to get through the questionnaire administration. Personal observation was carried out to familiarise the researchers with the study area and ascertain the actual situation. Ado-Ekiti is a city in southwest Nigeria, the state capital and headquarters of Ekiti State. The city has a population figure of 156,122 according to 1991 population census and rose to 308,621 in 2006 population census. It lies on latitude $7^{0} 37^{\prime} 16^{\prime}$ north of the equator and longitude $5^{0} 13^{\prime} 17^{\prime}$ east of the Greenwich Meridian. Ado-Ekiti has witnessed rapid population growth and urbanization since it became the capital city of Ekiti state. The city is about 344 kilometres north-east of Lagos, the most populous city in the country, the commercial and industrial centre of the country. Ado-Ekiti covered an area of 2.5 square kilometres (sq. km) in 1956 and by 1996; it had grown to about 19.6 sq. km. Presently the city covers an area of 36.7 sq. km [7, 10]. Figure 1 depicts Ekiti state within the regional context of Nigeria while Figure 2 is showing Ado-Ekiti within the context of Ekiti state.

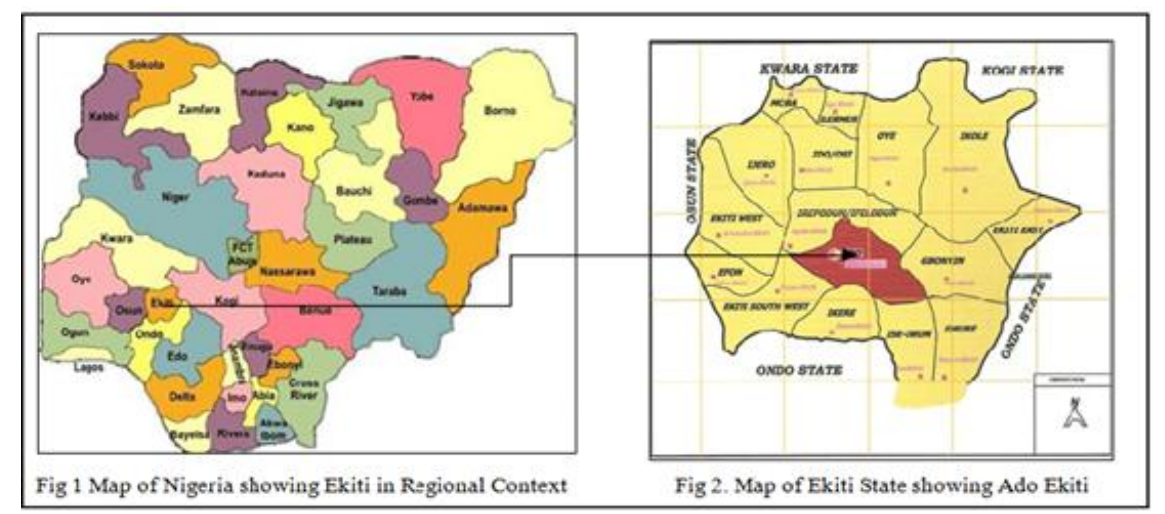

In determining the sample size for this study, consideration was not given to the entire population of Ado-Ekiti. This is because; the study area was specifically centred on a particular location. However, the sampling size was based on the available lock-up shops, hawkers, roadside traders and other roadside users. On this basis, a total number of 200 lock-up shops for various commercial activities were identified in various locations. In addition, 500 slots were added for hawkers, roadside tradersand members of drivers' unions as well as passengers and pedestrians. This brought the total numbers of population that were taken into consideration to 700.Based on[11] table of sampling size, 248 questionnaires were distributed. Stratified random sampling technique was adopted in the selection of the areas where the administration of questionnaires took place while the simple random sampling was applied in the selection of the respondents. Among the areas that were randomly selected include Atikankan, Old garage, Mugbagba, Irona, Oja Oba, Ojumose,Oke-Iyinmi and Idolofin areas. The researchers were able to retrieve only100 questionnaires out of the distributed 248 questionnairerepresenting 40.3 percent response rate. The 100 questionnaires were then used for the purpose of 
data analysis. The low percentage of the response rate was due to the non-siting activities of the respondents.In addition, those questionnaires that were not properly filled were discarded since they could not be used for the purpose of data analysis. Descriptive and inferential statistics were used to analyse the quantitative data. Descriptive in terms of frequency, percentage andhistograms were used to explain the respondents' profile, their capital base, non-usage of the designated shops as well as shops' attributes and parking facilities. Chi-square was used to test the significant relationship between street trading activities and residents' lifestyle within the CBD.The purposive random sampling technique was applied in the qualitative aspect of the data collection. The content analysis was applied to analyse qualitative aspect of the study.

\section{PRESENTATION OF DATA, RESULTS AND DISCUSSION}

This section presents the data, results and discussion of the analysis of the survey conducted. This covers the respondents' profile, their capital base, non-usage of the designated shops, shops attributes and parking facilities as well as the relationship between the street trading activities and the residents' within the CBD of Ado-Ekiti. The goods the traders are selling and their daily returns from sales were used to determine the trading activities while their socio-economic statuses are used to determine the residents' lifestyle. The qualitative judgement through content analysis was used to determine the environmental implications of these street trading activities on the residents within the CBD.

\subsection{Respondents' Profile}

\subsubsection{Sex and Age of Respondents}

The result of the survey shows that a substantial number of the female engaged in street trading activities compared with their male counterparts. From the study, 71 percent of the sampled street traders were females while 29 percent accounted for males as shown in Table 1. It can be inferred that females tend to opt for a less stress activities like petty trading that leads to street trading. The study also examined the age composition of the respondent and discovered that 53 percent are within the age bracket of 16 and 30 years while age range of 31-45 years accounted for 13 percent as shown in Table 1. The children aged 10-15 years accounted for 11 percent and age 51 years and above which is the least amount to 3 percent of the total sampled respondents. The youth that fall within the age group 16 and 30 years takes the lion share of the people that engage in street trading activities. This may be resulted from the fact that, youth are more energetic and resilient to face the hardship involved in various street trading activities.

\subsubsection{Educational level of Respondents}

The study reveals that 34 percent of the respondents attained primary school level while 57 percent of the respondents obtained secondary school certificate. Only 9 percent are graduates of various tertiary institutions such as technical colleges, colleges of education and the polytechnics. Table 1 presents the educational distribution of the respondents. Those that are graduates from tertiary institutions claimed to have been forced into street trading activities because of the high rate of unemployment within the nation. According to the interview conducted, one of the respondents stated that she was enforced into street trading activities as means of survival instead of her keep on waiting for job from the government.

\subsubsection{Employment of Respondents}

The study went further to examine the employment status of the respondents. 62 percent of the respondents are self-employed. 13 percent are civil servant, 6 percent are retiree and the remaining 19 percent accounts for those that either engage in the private sector or not employed as shown in Table 1. Moreover, the interview conducted reveals that majority of the self-employed traders are beneficiaries of the newly introduced self-employment scheme. They were granted soft loans, which encourage them to start small-scale business. However, this soft loan could not afford them the opportunity to get shop. In view of this, they have to resolve in street trading activities, although, some respondents that are government employed claimed to be involved in street trading activities after closing from the office work. They are majorly teachers from primary and secondary schools and the local government workers. In the interview conducted, it is discovered that some of them get involved in street trading in order to complement their salary especially when the payment of salary is not as regular as expected as a result of present economic recession in the nation. Furthermore,larger proportion of the respondents that are self-employed as reflects in Table 1confirms high number of the respondents involves in various street trading activities. 
Table 1. Respondents' profile

\begin{tabular}{l|l|l}
\hline Sex & Number of Respondents & Percentage \\
\hline Male & 29 & 29 \\
Female & 71 & 71 \\
Total & $\mathbf{1 0 0}$ & $\mathbf{1 0 0 . 0}$ \\
\hline Age & Number of Respondents & Percentage \\
\hline 10-15 years & 16 & 16.0 \\
16-30 years & 58 & 58.0 \\
31-45 years & 15 & 15.0 \\
46 years and above & 11 & 11.0 \\
Total & $\mathbf{1 0 0}$ & $\mathbf{1 0 0 . 0}$ \\
\hline Educational level of Respondents & Number of Respondents & Percentage \\
\hline Primary school level & 34 & 34.0 \\
Secondary School level & 57 & 57.0 \\
Graduates & 9 & 09.0 \\
Total & $\mathbf{1 0 0}$ & $\mathbf{1 0 0 . 0}$ \\
\hline Employment Status of Respondents & Number of Respondents & Percentage \\
\hline Self employed & 62 & 62.0 \\
Civil servants & 13 & 13.0 \\
Retiree & 06 & 06.0 \\
Private sector & 19 & 19.0 \\
Total & $\mathbf{1 0 0}$ & $\mathbf{1 0 0}$ \\
\hline
\end{tabular}

Source: Field survey, 2015

\subsubsection{Ethnicity of Respondents}

Ethnicity is another aspect that this study examined. The study discovers that majority of Yoruba engage in street trading and takes the larger percentage of the sampled respondents. This accounts for 53 percent of sampled respondents. The reason Yoruba people takes the larger percent may deduced from the fact that AdoEkiti, the study area is an indigenous city and this kind of activities does not attract non-indigene as such. This is followed by Ibo ethnicity and this accounts for 27 percent of the sampled respondents. To discover that the street traders that have second largest number is from Ibo ethnicity is not surprising. Culturally, it is observed that Ibo people engage more in business activities and they can get themselves involved in any business activities. In addition, they do not mind travelling to anywhere for the sake of business. The Hausas people cover the least percentage and this amount to 6 percent while those that are categorised among other ethnic groups such as Ebiras, Nupes and Ijaws make up the remaining 14 percent as presented in Figure 3.

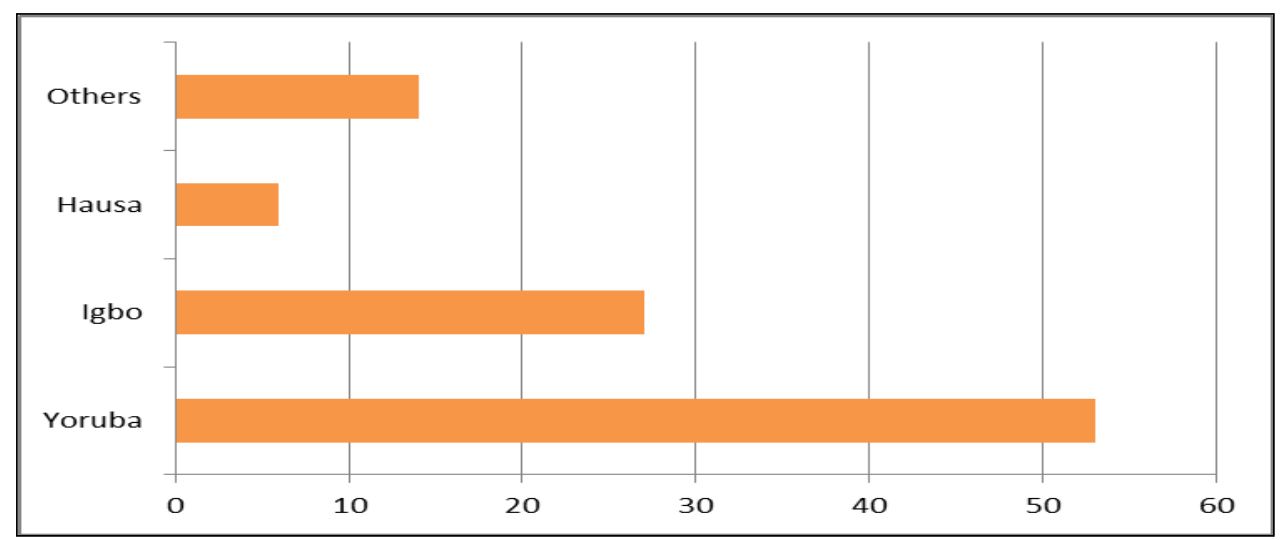

Fig.3: The ethnic groups of respondents; Source: Field Survey, 2015

\subsubsection{Capital Base of Traders}

The study reveals that most of the street traders have very low capital base. According to the investigation, 39 percent of the traders have a capital base below $\$ 5,000(\$ 15.87)$. 31 percent of the respondents have their capital base of $\$ 5,000$ - $\$ 10,000$ (\$15.87-\$31.74), while 27 percent have the capital base between $\$ 10,000-\$ 20,000$ (\$31.74-\$63.49), the rest 3 percent have the capital base above $\$ 20,000$ (\$63.49) as illustrated inFigure 4 . This shows the evidence that street trading requires little capital and easy to get involved. The study also investigates on the daily returns from sales and discovers that daily returns of the traders vary 
depends on the situation of thing each day. However, 4 percent of the traders makes below $\$ 1,000$ (\$3.17) per day, whereas 17 percent makes between $\$ 1,000$ (\$3.17) and $\$ 2,000(\$ 6.34)$. A larger set of the respondents representing 79 percent realises over $\$ 2,000$ per day (See fig. 5). With this, it can be deduced that street trading is thriving. This may be the reason why many people are engaging. In addition, the study investigated on items being sold by the street traders. The study reveals that 53 percent of the items sold are foodstuffs such as gari, vegetables, beans, rice and so on. This is followed by clothing which accounts for 26 percent of the goods being sold. However, the cloths the street traders sells are majorly the second hand wears while are new fabrics. The next category of goods is the provision, which accounted for 17 percent of the goods sold while items such as soaps, detergents, biscuits, compact disks, wristwatches and noodles among others accounted for the remaining 4 percent.
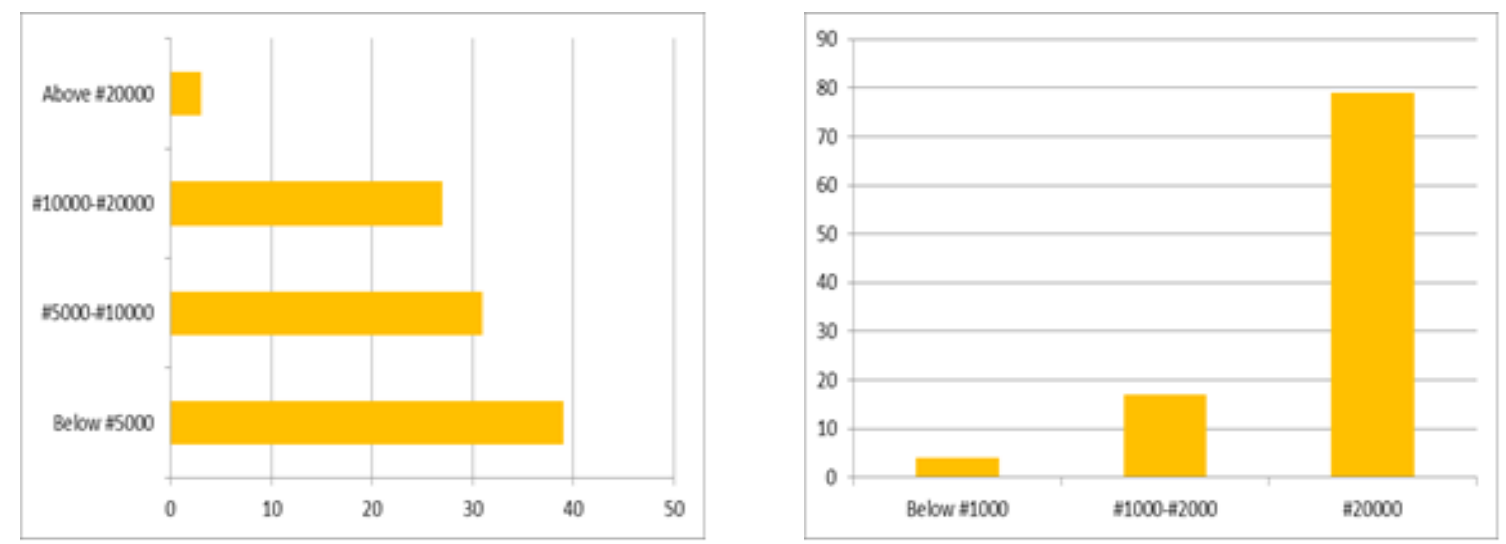

Fig. 4: Capital base of street traders; Source: Field Survey, 2015

Fig. 5: Average daily Sales of street traders;

Source: Field Survey, 2015

\subsubsection{Non-usage of designated shops}

The respondents were asked for the reasons they decided not to use the designated shops. Various reasons are responsible for non-usage of designated shops according to the respondents. 20 percent of the respondents gave their reason to be low patronage in the areas where the shops are located and hence in order for buyers to see their wares or goods, they moved to the major roads. Inadequate space in the market accounts for 9 percent while high cost of rents accounts for 18 percent. Easy accessibility and cheap price takes the larger percentage and this accounts for 53 percent as shown in figure 6. In addition, the traders have various ways of carrying their goods from one point to another. Among the sampled respondents, 9 percent of them use vehicles, 62 percent transports their goods by cart, 23 percent use human potters while the remaining 6 percent accounts for other means such as employment of wheelbarrow pushers services.

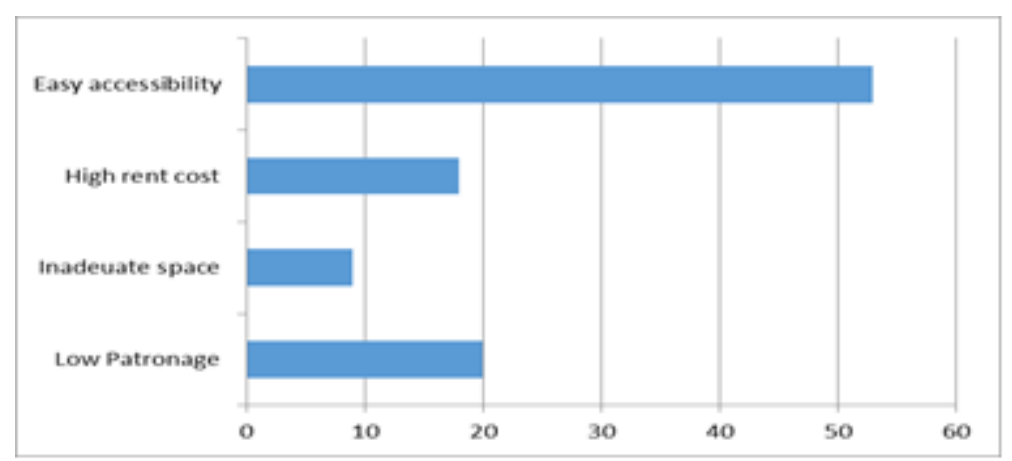

Fig 6Non usage of designated shops; Source: Field Survey, 2015

\subsection{Shops' Attributes and Parking Facilities}

\subsubsection{Age and Structural conditions of the buildings}

The study reveals that 9 percent of the on street traders use lock up shops, 29 percent uses open spaces and the remaining 62 percent uses open street trading. From the survey conducted, 7 percent of these structures have existed for between 1 and 3 years while 26 percent has been in existence between 4 to 6 years. The larger percentage of 62 percent has been in existence for quite a number of years even prior to the time the town became the capital city of Ekiti state. This confirms to the fact that street trading activities has been on for quite number of years. Only 5 percent of these structures seem to be good, 23 percent appeared to be fair, while 72 
percent of these structures are in a bad state thereby posing problems and constituting an eyesore in the environment.

\subsubsection{Parking Space}

It is discovered that there is no notable organised parking space within the central area of Ado-Ekiti, except a small one in front of Fajuyi Hall. The spaces are essentially small and those that are managing it are issuing tickets at the rate of twenty naira for a parking lot. Ado Progressive Union built and maintains the hall. Demand forlock-up shops and open stalls in the market is increasing but the non-provisionof parking space hinders the flow of traffic. Thisis becausetraders display their goods on the available space where vehicles supposed to park.

\subsection{Relationship between street trading activities and lifestyle of the traders}

Chi-square test was used to test the hypothesis that there is significant relationship between street trading activities and lifestyle of the residents within the CBD. The result shows that there is a significant relationship between street trading activities and the residents within the CBD of Ado-Ekiti. From the calculation, the critical value was 5.99 while the calculated value was $26.8 ; \mathrm{H}_{0}$ was rejected because the calculated value (26.8) was greater than the critical/tabulated value (5.99). This implies that the trading activities have implication on the residents.

\section{SUMMARY OF MAJOR FINDINGSAND CONCLUSION}

\subsection{Summary of Major Findings}

The major findings from the study include among others

(1) The study identifies three categories of street traders. The first category is those who operate on wheelbarrows in moving their goods from point to point. This group of traders pushes their wheelbarrows to a certain point, display their goods for about thirty minutes and then move to other locations. The second group includes those vegetable and small household goods hawkers who deliberately spread their goods on mats or small low tables arranged at the edge of the roads. This group also made use of planks, which they spread over the drains to display their wares. The third group are those who carry their articles of trade on their heads. This is the most mobile group as they are in continuous motion, moving from one place to another. In normal days, the activity of this group is dangerous to both vehicular and pedestrian traffic. Every five days when the traders from all over the town come to the market, the traffic and pedestrian situation become more chaotic.

(2) Another major finding of the research is that majority of the people engaged in street trading activities are young people between the age of sixteen and thirty years. Many of them only attained primary school level because of their financial constraints.

(3) Majority of the youths engage in street trading activities has been on increase since 1996 when Ekiti State was created. Large number of youth migrating to the state capital Ado-Ekiti with hope of getting job opportunity could not get one. As a result of this, they resolved in engaging in various trading activities.

(4) The study also identified six major roads which defined the boundaries of the central area and which presently function as major links to other areas of Ado-Ekiti. These roads are the Market roads, Ereguru, Okeyinmi, Orere-owu, Ogbon Oba, and Ogbon Ado. These vary in width from 4.0-6.0 metres. The absence of sidewalks being provided with these six major roads that connect with Ado-Ekiti always create traffic conflict between vehicular and pedestrians' traffic. This has been on increased on daily basis.

(5) Absence of organized parking lots for shoppers and stallholders to park their vehicles but always park along the road however reduce the vehicular right of way.

\section{CONCLUSION}

The stress of rapid urban population growth is often overwhelming. In some of the urban areas, more than one third of the urban population lived and engaged in some economic activities such as street trading. This study examined the implication of street trading activities on residents within the central business districts (CBD). The implications includeenvironmental degradation, traffic congestion, overcrowding within the CBD and deplorable state of social amenities. This necessitates urgent attention. It is on this basis, the authors make the following recommendations for ameliorating the effects of street trading activities on the residents within the Nigerian CBD. 


\section{RECOMMENDATIONS}

This study makes attempt to recommend some recommendations as means of ameliorating the challenges of street trading on residents within Nigerian CBD with particular reference to Ado-Ekiti.The decentralization of the commercial and business activities in both Oja and Bisi markets to other neighbourhoods will be of assistance in solving the implications of street trading activities. Areas such asOkesa, Irona and OdoAdo can be considered. It is believed that,ifsome household goods are moved to such neighbourhoods, the pressure on the Oba and Bisi markets will be reduced and buyers will not travel far to purchase items. The redesign, reconstruction and redevelopment of Oba and Bisi markets can make them more functional. This is in line with modern trend in city development. This can be achieved via the public-private partnership approach (PPP).The proposed new market should make provision for variety of shops, stalls and offices as well as enough open spaces for open-air trading and well-structured parking lots. The public and private investors can jointly perform the administration of the market. Only a one-sided vehicular parking needs to be allowed along all market roads while removal of wares from shoulder and Kerbs of the road to allow free vehicular and pedestrian movement will also help a lots. The youths can be encouraged to venture into another area of investment such as agriculture. Youths can be encouragedat the same time to attend vocational training where they can acquire skills for their sustenance especially when they get to the old age. This is because of the risk been involved in street trading activities.More emphasis needs to be placed on the core areas of the city by the government for proper planning, execution, monitoring and enforcement of physical development. Lastly, the authors are of opinion that if the aforementioned suggestions and designing of ultra-modern markets, motor parks and public enlightenment can be properly implemented, they may be of assistance to solve the problems of street trading activities especially on residents within CBD in developing countries with particular reference to Ado-Ekiti.

\section{REFERENCES}

[1] T. Agbola, Readings in urban and regional planning(Macmillan Books, Ibadan 2004)

[2] A.L. Mabogunje "Towards an urban policy in Nigeria". Journal of Economics and Social Studies Vol.1(1974):

[3] S. K. Bhowmik (2003) Urban responses to street trading in India: Africa's at the urban research symposium on urban development for economic development for economic growth and poverty reduction, World bank, Washinton D.C.

[4] B. Alison, M Lyons and I Dankoco; Street traders and the emerging spaces for urban voice and citizenship in African cities Urban Studies Journal Limited 2010

[5] A. Ademola; Street trade; symbol of tradition. The daily Sketch, 19907 (34)

[6] D. O. Taiwo and A.A Adebayo., Building the resilience of community to disaster; case study of Ado-Ekiti, Nigeria , International Journal of Engineering Science and Innovative Technology, 3(4), 2014,

[7] O. Oriye. Urban expansion and urban land-use in Ado-Ekiti. Nigeria. American Journal of Research Communication. 1(2): 2013 (128-139.)

[8] M.T. Atoyebi. Alternative strategies for resettlement of street traders in Ilorin. Murp thesis submitted to the Department of Urban and Regional Planning, University of Ibadan., 1984

[9] O.O. Ayeni, Street trading in Ibadan: focus on Lebanon-Amigun-Felele-Agbeni and Gege streets, ond thesis submitted to the Department of Town Planning and Estate Management, The Polytechnic, Ibadan., 1980

[10] D.Taiwo and K Ifesanya; The Impact of urbanization on pattern of physical development in emerging urban fringes of Ado Ekiti JurnalTeknologi (Sciences \& Engineering) 77(14) 2015, (99-105)

[11] Krejcie and Morgan: Determining sample size from a given population; 1970 